\title{
TECHNOLOGY OF BARLEY BREEDING FOR RESISTANCE TO SMUT FUNGI
}

\author{
Aleksandra V. Zaushintsena and Svetlana V. Svirkova*
}

Kemerovo State University, Krasnaya Str. 6, Kemerovo, 650043, Russian Federation

Received October 10, 2017;

* e-mail: svsvirkova@yandex.ru

Accepted in revised form November 15, 2017;

Published December 30, 2017

\begin{abstract}
The technology of creating varieties of barley resistant to the smut diseases has been developed. Their cultivation will help to reduce crop losses, increase the profitability of seed production, improve the quality of seeds, and reduce the environmental risk from the use of chemical plant protection products. This technology was first implemented in the Kemerovo Region in 1988-1999. The wide distribution of species Ustilago nuda (Jens.) Kell. et Sw. (65\%) and U. nigra Tapke (35\%) was revealed. The covered smut (Ustilago hordei (Pers.) Kell. Et Sw.) was registered in individual collection varieties. The first and tenth races of a loose smut and the sixth race of a black loose smut were identified. The sources of individual and group immunity to the smut fungi from the world gene pool of barley are distinguished: Moskovsky 3/125, Suzdalets, Ramos (Moscow Region); Kazer (Rostov Region); line 3 KM-1192 (Belarus); Kumir Odessky (Ukraine); Guardian (Canada). The donor properties of resistance to a loose smut in the Bagan variety, line 53 HVS ${ }^{91} / 76$, line 1899 were studied. They are recommended for use in breeding programs. With their participation a new hybrid fund was created. Variability and inheritance of quantitative traits of productivity of hybrids was studied. To select the recombinants immune to the loose smut in combination with high productivity, the most promising combinations of hybrids have been identified: Bagan $\times$ Viner; Bagan $\times$ KM-16; $1.53 \mathrm{HVS} 91 / 76 \times$ KM-7; KM-7 × 1. 1899; 1. $1899 \times$ KM-7. Among them, prospective breeding lines have been selected. The results of the implementation of technology elements in the selection of barley for resistance to smut fungi is the creation of immune highly productive varieties of a new generation: Simon and Luka (Kemerovo Region). They are included in the State register of breeding achievements since 2004.
\end{abstract}

Keywords: Selection, variety, smut diseases, race, genetic source, genetic donor, inheritance, inheritability, overall combining ability (OCA).

DOI $10.21603 / 2500-1418-2017-2-2-22-32$

\section{INTRODUCTION}

Barley is a traditional crop in Russian agriculture. It has grain-bearing and food value. The publication of Stephen E. Ulrich [1] noted that $1 \mathrm{~kg}$ of barley grain contains, on average, 1.15 fodder units, $85 \mathrm{~g}$ of digestible protein, $10-17 \%$ of protein, $4-9 \%$ of b-glucan, $2-3 \%$ of free lipids, $61.6 \%$ of nitrogen-free extractives, $2.7 \%$ of ash, $1.5-2.5 \%$ of mineral substances, of which phosphorus and silicic acid compounds predominate. Barley protein is balanced by amino acids: lysine, methionine, and tryptophan. Barley grain is rich in starch (55-68\%), contains vitamins B1, $\mathrm{B} 2, \mathrm{C}$ and $\mathrm{E}$. Total fiber is $11-34 \%$, and soluble fiber is $3-20 \%$. Bare or peeled barley grain contains $11-20 \%$ of total fiber, $11-14 \%$ of insoluble fiber and $3-10 \%$ of soluble fiber. After peeling, the content of insoluble fiber, protein, ash elements and free lipids in grain decreases, but the content of starch and beta-glucan increases.

The energy value of $1 \mathrm{~kg}$ of green barley mass is $0.22 \mathrm{EFU}$, the content of crude protein is $4.3 \%$, fiber $-5.9 \%$, calcium $-1.2 \mathrm{~g}$, phosphorus $-1 \mathrm{~g}$ [2]

Studies of the chemical composition of barley grain have confirmed its positive effect on the animal and human organism. It has a high nutritional value and health benefits. The grain combines a low fat content, a sufficient amount of complex carbohydrates (mainly starch) and a well-balanced protein. Grain products are recommended for replenishing energy. Barley grain can satisfy the human need for essential amino acids, minerals, vitamins and antioxidants. Scientists have proved that the use of barley is good for health [1]. Contained in the grain b-glucan helps reduce cholesterol in the blood. The high content of fiber and other components give a feeling of satiety. This helps to control excess weight. In addition, cellulose accelerates the passage of food in the gastrointestinal tract.

In Western Siberia, obtaining a high and stable yield of barley grain and ecologically safe products is limited by a significant damage to cultivated varieties of diseases. Among them, diseases caused by various types of smut fungi are most harmful: Ustilago nuda (Jens.) Kell. et Sw.), U. nigra Tapke. and Ustilago hordei (Pers.) Kell. et Sw. They damage the spike and turn it into a black dense or dusty mass of spores. Therefore, the yield in diseased plants is greatly reduced or lost entirely. The loss of spring barley harvest as a result of smut diseases can be from 10 to $30 \%$, while epiphytosis - up to $50 \%-100 \%[3,4,5]$. The ability of the smut fungi to cause obvious and hidden crop losses was noted in the works of known phytopathologists of Siberia [6] and other well-known

Please cite this article in press as: Zaushintsena A.V. and Svirkova S.V. Technology of barley breeding for resistance to smut fungi. Science Evolution, 2017, vol. 2, no. 2, pp. 22-32. DOI: 10.21603/2500-1418-2017-2-2-22-32.

Copyright (C) 2017, Zaushintsena et al. This is an open access article distributed under the terms of the Creative Commons Attribution 4.0 International License (http:// creativecommons.org/licenses/by/4.0/), allowing third parties to copy and redistribute the material in any medium or format and to remix, transform, and build upon the material for any purpose, even commercially, provided the original work is properly cited and states its license. This article is published with open access at http:// scienceevolution.ru/ 
scientists $[7,8,9]$. Hidden losses cannot be accounted for by external inspection of crops. They are expressed in the inhibitory effect of the causal agent on the plant from the moment of germination to maturation of the seeds. Hidden losses cause a decrease in the germination of seeds, the height of stem, the number of grains per spike and worsen the grain filling.

The prevalence of smut disease in barley in the world crop practice tends to appreciably increase $[4,5,10,11]$. Scientists associate this with favorable for the development of pathogen weather conditions, low level of agricultural technology, physiological characteristics and variability of pathogenic species of the pathogen, inadequate immunity of cultivated varieties. In Western Siberia, in 2015, the greatest incidence of smut diseases in barley was noted in the Altai Territory (5.04 thousand hectares), Omsk (2.25 thousand ha), Novosibirsk (2,0 thousand hectares) and Kemerovo (1.33 thousand hectares) [12]. In the main grain-growing areas of the region, epiphytotics are periodically observed (1-3 times in 10 years).

An ecological justification for all methods of increasing the stability and productivity of barley agrocenoses is important. To achieve a safe phytosanitary situation with a high economic and ecological effect, we have developed a special technology for barley selection for resistance to fungi. Its implementation is possible according to the following scheme (Figure 1).

Research objective: development of barley selection technology for resistance to the smut fungi and its implementation in the breeding process. Creation of new immune varieties using this technology and adaptation to agrocenosis will reduce yield losses, increase the profitability of seed production, improve the quality of the products obtained and reduce the environmental risk from the use of chemical plant protection products.

This technology was implemented in the Kemerovo Region in 1988-1999. The active use of its elements has made it possible to obtain varieties of barley resistant to barley diseases in the following decades.

\section{MATERIALS AND METHODS}

Species composition of the population of smut fungi is determined by the nature of germination of teliospores in liquid nutrient media (the method of "wet chambers"). The study of the race composition of the species of smut fungi was carried out in the field on an infectious background according to the method by N.I. Vavilov All-Russia Institute of Plant Growing ${ }^{1}$ [13]. The basis for the identification of races are signs of virulence and aggressiveness of the pathogen. They are basic. They are determined by the degree of damage to the varieties-differentiators. The obtained results were compared with the key for determining physiological races. According to an additional set of varieties with identified resistance genes, the virulence formula of the studied race is determined.

\footnotetext{
${ }^{1}$ V. I. Vavilov All-Russia Institute of Plant Growing - N. I. Vavilov Federal State Budget Scientific Institution "Federal Research Center All-Russian Institute of Plant Genetic Resources"
}

The types of pathogens studied differ in developmental biology. Therefore, the technology of infection with pathogens of different types of smut fungi consisted of different stages. Infection of seeds with a black loose smut was carried out a month before planting according to the method of V.I. Krivchenko and A.P. Khokhlova [13]. The RT-1 apparatus (tissue grinder) was used. It was used to violate the integrity of the seed films. The seeds were inoculated in a nutrient solution of Teliosporum U. nigra Tapke suspension. Localization of teliospores was carried out under the films of seed beetles or on their exposed surface. An Andrey variety susceptible to a black loose smut from the Kirov Region (indicator variety) served as a control of the quality of the infection of plants.

The creation of an infectious background on a barley loose smut was also done artificially. The causal agent of the disease, Ustilago nuda (Jens.) Kell. et Sw.), under natural conditions has a two-year cycle. In the first year, during the beginning of flowering, the flowers were inoculated with a pathogen spore suspension. In the spring of the following year, the infected seeds were planted in the soil, the plants were evaluated according to the number of affected spikes. Artificial infection of spikes was carried out with a syringe method [14]. It was first proposed by foreign scientists Z. Kirai, Z. Clement, F. Shoymoshi, I. Veresh [15] and adapted to work with barley breeders from North-East Agricultural Research Institute, N.A Rodina and Z. G. Efremova [16].

The infection technology is as follows: 1. An aqueous suspension of viable teliospores was injected into each flower of the spike with a conventional medical syringe with a thin needle. 2. The infected spikes were coated with insulators of parchment paper. As an indicator variety, a highly susceptible to a loose smut variety Odessky 100 from Ukraine was used. 3. Seeds inoculated with teliospores were planted in soil to a depth of $5-6 \mathrm{~cm}$. 4. The percentage of damage to the plants was determined during the earing phase. To do this, we calculated sick and healthy plants and stems in the soil lot. The degree of damage to the varieties was converted into the reaction type $(\mathrm{R}-\mathrm{S})$ and classified according to the international scale:

- resistance, $\mathrm{R}$ (damage to plants and stems up to $10 \%)$

- susceptibility, S (more than 10\% damage to plants and stems at the soil lot).

To unify the results on the resistance of varieties to Ustilago nuda (Jens.) Kell. et Sw.) and U. nigra Tapke, the placement of samples into certain classes is conventionally carried out:

0 - high resistance, no damage to plants and stems;

I - practical resistance, damage to plants and stems does not exceed $5 \%$;

II - weak susceptibility, damage to plants and stems does not exceed $25 \%$;

III - average susceptibility, damage to plants and stems does not exceed $50 \%$;

IV - strong susceptibility, damage to plants and stems more than $50 \%$. 


\section{TECHNOLOGY}

2. Analyzing the input breeding material for barley for resistance to smut fungi in artificial infectious backgrounds and search for the sources of individual and herd immunity from among the grobal gene pool.

HYBRIDOLOGICAL ANALYSIS

3. Determining the donor properties of separated genetic sources in tester breedings with susceptible varieties that are high-yielding and adapted to local conditions.

4. Inclusion of immunity donors in all programs of breedings in different directions of selection.

5. Investigation of variability and inheritance of quantitative production characters in hybrids obtained on the basis of new donors of immunity to smut types.

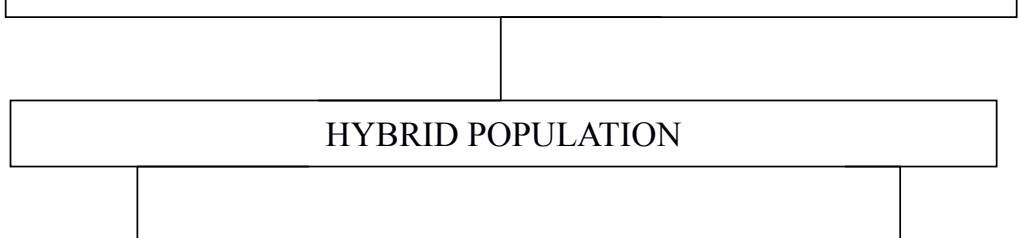

1. Studying the species and race composition of the region's smut fungi

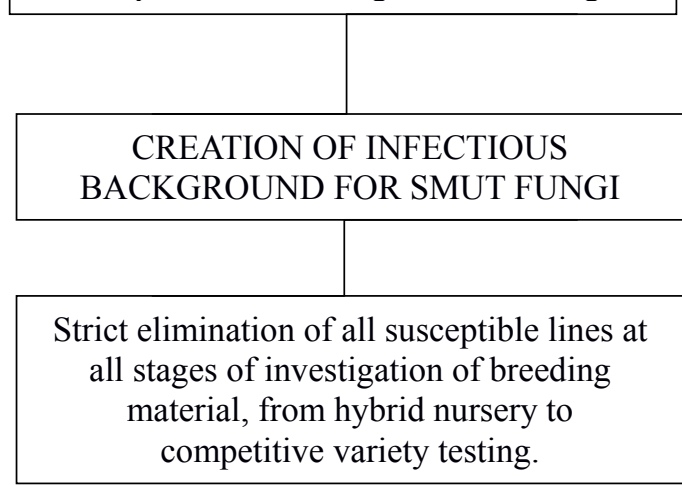

6. Selection of immune forms featuring high values of productive tilling capacity and numbers of grains in a head in hybrid populations of barley.

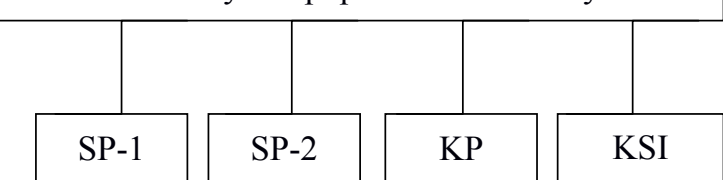

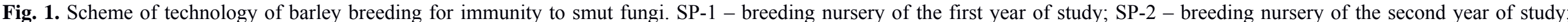
$\mathrm{KP}$ - control nursery; KSI - competitive variety testing. 
We studied 130 varieties of barley from the world collection of N.I. Vavilov All-Russia Institute of Plant Growing with respect to resistance to smut fungi. Selection of varieties was carried out taking into account the natural and climatic features of the zone. The collection includes modern varieties of Siberia, the European part of Russia, Ukraine, Belarus, Scandinavian countries, Northern and Central Europe, America and Canada.

A valuable hybrid fund was obtained by crossing plants in the field conditions. A total of 24 hybrid populations were obtained. Reciprocal crosses were conducted between immune and highly productive parental forms. As the immune parental forms, the line $53 \mathrm{HVS}^{91} / 76$ from Belarus, the line 1899 from the Kemerovo Region and the Bagan variety from the Novosibirsk Region were involved in the hybridization. High-productive parents were barley lines created in the Kemerovo Region - KM-6, KM-7, KM-16 and the old-fashioned variety Viner. Parental forms, hybrids $\mathrm{F}_{1}$, $\mathrm{F}_{2}$ are included in the hybridologic analysis in terms of the resistance reaction to the loose smut and in a comparative study on the development of the elements of productivity. In hybrid populations of $\mathrm{F}_{2}$, healthy plants were selected. They had high tillering and good grain productivity. The selection material was represented by samples from breeding nurseries SP-1, SP-2, KP, KSI.

For the processing of experimental data and analysis of the results obtained, classical methods and techniques were used:

- statistical and biometric methods in plant breeding and seed production [15];

- methods of dispersion and correlation [16];

- linear-tester analysis [19] in the presentation of

RA. Tsilke and L.T. Prisyazhnaya [20,21];

formulas F. Petr, K. Frey [22] to calculate the nature of inheritance and inheritability estimates; method of G.S. Voskresenskaya and V.I. Shpot [23] for the determination of transgression indices; - analysis of splitting of $\mathrm{F}_{2}$ hybrids in terms of resistance to a loose smut according to P.F. Rokitsky [24]; methodical recommendations of M.V. Lukyanova and co-authors [25] for interpreting the results in studying the effects of the overall combining ability (ACS) of varieties.

For counting and observation, in the collection and breeding nurseries in natural conditions, the following were used:

- procedural guidelines for studying the collection of barley and oats [26];

- method of state testing of agricultural crops [27].

Results and discussion. Fundamentals of plant immunity have been developed by N.I. Vavilov [28]. $\mathrm{He}$ identified the need to introduce a geographical principle into immunity studies. Therefore, phytopathological studies of grain crops in Siberia repeatedly confirmed the feasibility of studying the species and race composition of the population of smut fungi $[6,29,30]$.

The population of barley smut fungi is being studied in the Kemerovo Region since 1988. In the course of analyzing infected plants from the collection of barley, three types of smut were determined: Ustilago nuda (Jens.) Kell. et Sw.) (60-65\%), $U$. hordei (Pers.) Kell. et Sw. (40-45\%), U. nigra Tapke (5-9\%). The population of the smut, which was collected from plants of industrial crops on varieties Odessky 100 and Talovsky 34, was represented by a loose smut - 75-80\%. Variety Talovsky 34 (20-25\%) was damaged by a covered smut. There was no variety of a black loose smut (Figure 2).

Since 1996, the farms have changed varieties. Instead of the Talovsky 34 variety, a fast-growing barley variety Andrey was included in the state variety register for use in production. The Elf variety was adopted as a variety with a late maturity.

The population of smut fungi was analyzed for 3 years (1997-1999). U. nuda (Jens.) Kell. et Sw. leads in terms of dissemination $-63-70 \%$. Variety U. nigra Tapke. $-25-30 \%$ introduced with Andrey variety from the Kirov Region. Population of U. hordei (Pers.) Kell. et Sw. was found only on the collection samples of barley. Under natural conditions, the Novosibirsky 80 variety was damaged by this pathogen by $0.48 \%$, and the Samson sample from Canada was damaged by $0.02 \%$.

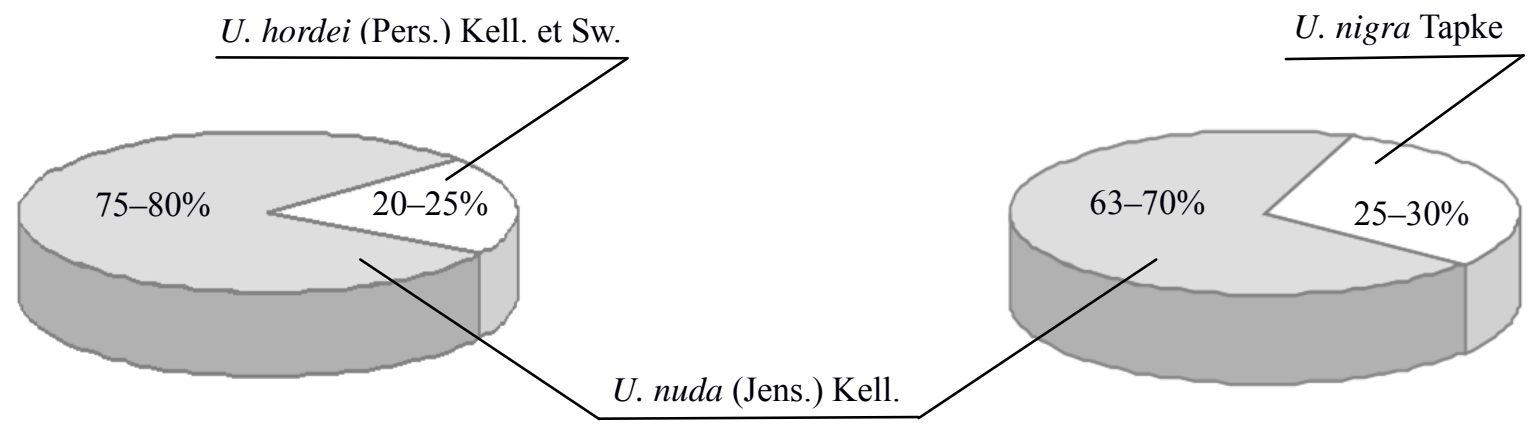

(a)

(b)

Fig. 2. Variety composition of the population of smut fungi in the south of Western Siberia: (a) 1988-1995;

(b) 1997-1999. 
In the selection process, it is necessary to take into account the virulence of the pathogen agent of the disease. For this purpose, it is recommended to monitor the race composition of pathogens. Analysis of the experimental data on the susceptibility of varietiesdifferentiators (test varieties) showed the inhomogeneity of the causal agent $U$. nuda (Jens.) Kell. et Sw. (Table 1). Test varieties were damaged from 0 to $76.1 \%$. All collections of a loose smut were virulent on varieties OAS-21, Mutant 3, Montcalm, Trebi. There were no virulent races to the Keystone variety. In parallel with the study of a standard set of differentiation varieties, varieties with identified resistance genes were analyzed (Table 2). This allowed to identify the most effective resistance genes in the south of Western Siberia - $\mathrm{Un}_{3}, \mathrm{Un}_{6}, \mathrm{Un}_{8}$. Varieties with the genes $\mathrm{Un}_{1}, \mathrm{Un}_{4}, \mathrm{un}_{7}, \mathrm{Un}_{9}, \mathrm{Un}_{10}, \mathrm{Un}_{11}, \mathrm{Un}_{12}$ had in some cases a low breeding value due to susceptibility to the smut. Information was received on the preservation of resistance to the population of the pathogen of a loose smut from the Odessky 100 variety in varieties with $\mathrm{Un}_{13}$ and $\mathrm{Un}_{14}$ genes.

The race composition $U$. nuda (Jens.) Kell. et Sw., collected from plants of the Odessky 100 variety is represented by a strongly virulent race 1 . It was distinguished in Kemerovo, Belovo, Leninsk-Kuznetsk, and Promyshlennovsky districts. Here the main acreage under barley is concentrated. Its formula for virulence - 1-1,4,7,9,10,11,12. Race 1 overcomes the barrier of the genes $\mathrm{Un}_{1}, \mathrm{Un}_{4}, \mathrm{un}_{7}, \mathrm{Un}_{9}, \mathrm{Un}_{10}, \mathrm{Un}_{11}, \mathrm{Un}_{12}$, but the varieties with $\mathrm{Un}_{3}, \mathrm{Un}_{6}, \mathrm{Un}_{8}, \mathrm{Un}_{13}, \mathrm{Un}_{14}$ genes were resistant. The population of the smut from the Kuznetsky variety is also represented by race 1 with the formula of virulence - 1-1,4,7,9,10,11,12,13,14. The introduction of the Andrey variety into the production process led to the spread of a new race of a loose bunt, 10 with a virulence formula of $10-1,7,9,10,11,12,13$. According to the Department of Immunity of All-Russia Institute of Plant Growing, the 10 th race of $U$. nuda (Jens.) Kell. et Sw. is the most common in the Kirov region.

The racial composition of the black loose smut, according to the key, is represented by race 6 (Table 3 ). Population of the $U$. nigra Tapke is virulent on the varieties Hannchen, Lion, Pannier and Trebi. This race is registered by A.I. Shirokov and E.V. Paderina in the Omsk region, as well as V.I. Krivchenko - in the Volgograd, Odessa, Zaporozhye, East Kazakhstan regions [31, 32].

During the second stage, a test was conducted on the provocative background of infection with varieties of spring barley from the world gene pool of All-Russia Institute of Plant Growing, Siberia, and promising breeding lines.

A wide range of variation in susceptibility to the pathogen was noted (from 0 to $73.2 \%$ ). It depended on the genetic protection of the variety. Barley samples are differentiated according to resistance classes and types of reaction to pathogens of the disease. The stability of the samples was compared with the susceptible standard varieties - Odessky 100 and Andrey. Depending on the conditions of the year, the Odessky 100 variety was damaged by $20.8-73.2 \%$, the Andrey variety - by $26.5-61.7 \%$. By reaction to the black loose smut they were weak- and medium-susceptible $-9.4 \%$ (Odessky 100) and 41.1\% (Andrey). The susceptibility to pathogens on a natural background was found in the range $0.008-0.11 \%$ for the Odessky 100 variety and $0.075-0.43 \%$ for the Andrey variety. The Elf variety is more immune among those grown in production. According to the institution-originator, the resistance of the variety to $U$. nuda (Jens.) Kell. et Sw. is controlled by the $\mathrm{Un}_{8}$ gene. In our study, a variety loss of $0.007 \%$ under natural conditions and $4.2 \%$ on an artificial background was noted. The variety was practically resistant (1.5\%) to U. nigra Tapke.

When artificially infection with a loose smut (Ustilago nuda (Jens.) Kell. Et Sw.) of plants of collectible barley varieties, about $40 \%$ of the samples had a very high resistance to the pathogen $(0.0 \%), 13 \%$ - practical resistance (up to $5 \%$ ). The weak-responsive group (5-25\%) included 29 samples. Groups of medium and highly susceptible samples were $9-11 \%$. High immunity to a loose smut was confirmed in known and newly selected samples, in new breeding lines. They were obtained by the method of directed selection on a provocative background of infection of plants.

For many years, no damage by the causal agent Ustilago nuda (Jens.) Kell. et Sw. to the following varieties was detected: Keystone, Paragon, Brock (Canada), CI 13662, CI 13664, Fox (USA), Jet (Ethiopia). Their resistance is also noted in the works of N.A. Surin and N.E. Lyakhova in Eastern Siberia, by S.F. Mordanov and A.M. Camelina in the Far East $[33,34]$. These varieties were used in breeding for increasing the immunity of plants. With their participation, new modern varieties and targeted immune lines have been created.

Among the Siberian gene pool, the unique resistance to Ustilago nuda (Jens.) Kell. et Sw.) for two or three decades, the variety Bagan (Novosibirsk region) showed. Its breeding background has parental forms of Siberian origin - Omsky 13709 variety and k-122 breeding lines. A property of resistance was passed by two donor varieties from America - Brock and Keystone. They have effective resistance genes $\mathrm{Un}_{3}$ and $\mathrm{Un}_{6}$.

The immune line 50 from the Omsk region was used as a promising source in breeding crosses. Its breeding background has an American variety Fox and a highly productive variety from Siberia - Olymp. The Jet variety and line 50 were crossed, and sustainable plants in the population of $\mathrm{F}_{2}$ were selected. As a result, a new perspective line has been identified. Over the past 20 years, it had a high resistance to damage by species of spike smut: Ustilago nuda (Jens.) Kell. et Sw.), U. hordei (Pers.) Kell. et Sw., U. nigra Tapke. 
Table 1. Reaction of differentiation varieties to inoculation with U. nuda (Jens.) Kell. et Sw. (Kemerovo, 1997-1999)

\begin{tabular}{|c|c|c|c|c|c|c|c|c|}
\hline \multirow[b]{2}{*}{ Year } & \multirow{2}{*}{$\begin{array}{l}\text { Population characteristic: variety from } \\
\text { which samples were taken and the } \\
\text { growing region }\end{array}$} & \multicolumn{6}{|c|}{ Reaction of differentiation varieties } & \multirow{2}{*}{$\begin{array}{c}\text { Race } \\
\text { number }\end{array}$} \\
\hline & & $\begin{array}{c}\text { k-16930 } \\
\text { Regal }\end{array}$ & $\begin{array}{l}\mathrm{k}-15554 \\
\text { OAC- } 21\end{array}$ & $\begin{array}{l}\text { k-20441 } \\
\text { Mutant } 3\end{array}$ & $\begin{array}{c}\text { k-17447 } \\
\text { Montcalm }\end{array}$ & $\begin{array}{c}\text { k-11835 } \\
\text { Trebi }\end{array}$ & $\begin{array}{c}\text { k-19304 } \\
\text { Keystone }\end{array}$ & \\
\hline \multirow{4}{*}{1997} & Odessky 100, Kemerovo District & $47.5 \mathrm{~S}$ & $45.9 \mathrm{~S}$ & $59.3 \mathrm{~S}$ & $40.3 \mathrm{~S}$ & $42.0 \mathrm{~S}$ & $0.0 \mathrm{R}$ & 1 \\
\hline & Odessky 100, Belovo District & $40.1 \mathrm{~S}$ & $11.8 \mathrm{~S}$ & $51.3 \mathrm{~S}$ & $41.0 \mathrm{~S}$ & $52.8 \mathrm{~S}$ & $0.0 \mathrm{R}$ & 1 \\
\hline & Odessky 100, Leninsk-Kuznetsky District & $48.2 \mathrm{~S}$ & $33.3 \mathrm{~S}$ & $48.2 \mathrm{~S}$ & $33.2 \mathrm{~S}$ & $55.2 \mathrm{~S}$ & $0.0 \mathrm{R}$ & 1 \\
\hline & Odessky 100, Promyshlennovsky District & $\underline{53.6} \mathrm{~S}$ & $53.2 \mathrm{~S}$ & $61.0 \mathrm{~S}$ & $37.4 \mathrm{~S}$ & $56.5 \mathrm{~S}$ & $0.0 \mathrm{R}$ & 1 \\
\hline \multirow{3}{*}{1998} & Odessky 100, Kemerovo District & $25.6 \mathrm{~S}$ & $52.8 \mathrm{~S}$ & $36.8 \mathrm{~S}$ & $15.0 \mathrm{~S}$ & $57.1 \mathrm{~S}$ & $0.0 \mathrm{R}$ & 1 \\
\hline & Kuznetsky, Kemerovo District & $\underline{33.3 \mathrm{~S}}$ & $40.0 \mathrm{~S}$ & $50.0 \mathrm{~S}$ & $25.0 \mathrm{~S}$ & $36.7 \mathrm{~S}$ & $0.0 \mathrm{R}$ & 1 \\
\hline & Andrey, Kemerovo District & $36.4 \mathrm{~S}$ & $14.3 \mathrm{~S}$ & $58.1 \mathrm{~S}$ & $76.1 \mathrm{~S}$ & $37.5 \mathrm{~S}$ & $0.0 \mathrm{R}$ & 1 \\
\hline \multirow{3}{*}{1999} & Odessky 100, Kemerovo District & $12.3 \mathrm{~S}$ & $14.0 \mathrm{~S}$ & $30.0 \mathrm{~S}$ & $17.3 \mathrm{~S}$ & $37.5 \mathrm{~S}$ & $0.0 \mathrm{R}$ & 1 \\
\hline & Kuznetsky, Kemerovo District & $11.0 \mathrm{~S}$ & $38.6 \mathrm{~S}$ & $38.7 \mathrm{~S}$ & $34.0 \mathrm{~S}$ & $34.7 \mathrm{~S}$ & $0.0 \mathrm{R}$ & 1 \\
\hline & Andrey, Kemerovo District & $5.4 \mathrm{R}$ & $11.0 \mathrm{~S}$ & $19.0 \mathrm{~S}$ & $17.7 \mathrm{~S}$ & $11.1 \mathrm{~S}$ & $0.0 \mathrm{R}$ & 10 \\
\hline
\end{tabular}

Note: The numerator gives the damage percentage, the denominator - the type of reaction

Table 2. Differentiation of Ustilago nuda (Jens.) Kell. et Sw. races on varieties with identified resistance genes (Kemerovo, 1997-1999).

\begin{tabular}{|c|c|c|c|c|c|c|c|c|c|c|c|c|c|c|}
\hline \multirow[b]{2}{*}{ 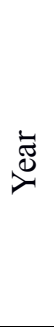 } & \multirow[b]{2}{*}{$\begin{array}{l}\text { Population characteristic: } \\
\text { variety from which samples } \\
\text { were taken and the growing region }\end{array}$} & \multirow[b]{2}{*}{ 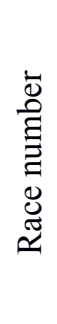 } & \multicolumn{11}{|c|}{ Reaction of differentiation varieties } & \multirow[t]{2}{*}{ Formula of virulence } \\
\hline & & & 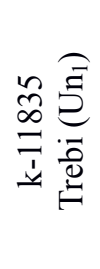 & 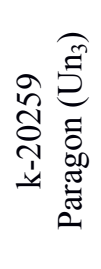 & 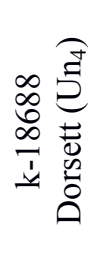 & 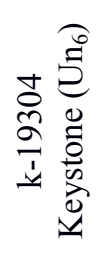 & 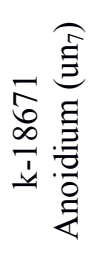 & 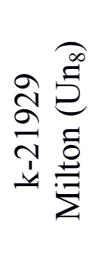 & 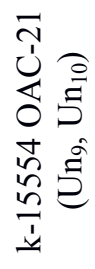 & $\begin{array}{l}\underset{\Xi}{\Xi} \\
\stackrel{\infty}{D} \\
\stackrel{\infty}{N} \\
\infty \\
-\end{array}$ & 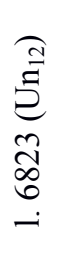 & 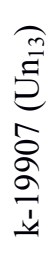 & 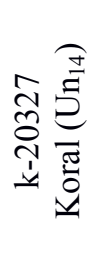 & \\
\hline \multirow{4}{*}{$\hat{\sigma}$} & Odessky 100, Kemerovo District & 1 & $\mathrm{~S}$ & $\mathrm{R}$ & $\mathrm{S}$ & $\mathrm{R}$ & $\mathrm{S}$ & $\mathrm{R}$ & $\mathrm{S}$ & - & - & - & - & $1-1,4,7,9,10$ \\
\hline & Odessky 100, Belovo District & 1 & $\mathrm{~S}$ & $\mathrm{R}$ & $\mathrm{S}$ & $\mathrm{R}$ & $\mathrm{S}$ & $\mathrm{R}$ & $\mathrm{S}$ & - & - & - & - & $1-1,4,7,9,10$ \\
\hline & Odessky 100, Leninsk-Kuznetsky District & 1 & $\mathrm{~S}$ & $\mathrm{R}$ & $\mathrm{S}$ & $\mathrm{R}$ & $\mathrm{S}$ & $\mathrm{R}$ & $\mathrm{S}$ & - & - & - & - & $1-1,4,7,9,10$ \\
\hline & Odessky 100, Promyshlennovsky District & 1 & $\mathrm{~S}$ & $\mathrm{R}$ & $\mathrm{S}$ & $\mathrm{R}$ & $\mathrm{S}$ & $\mathrm{R}$ & $\mathrm{S}$ & - & - & - & - & $1-1,4,7,9,10$ \\
\hline \multirow{3}{*}{$\begin{array}{l}\infty \\
\stackrel{2}{二}\end{array}$} & Odessky 100, Kemerovo District & 1 & $\mathrm{~S}$ & $\mathrm{R}$ & $\mathrm{S}$ & $\mathrm{R}$ & $\mathrm{S}$ & $\mathrm{R}$ & $\mathrm{S}$ & $\mathrm{S}$ & $\mathrm{S}$ & $\mathrm{R}$ & $\mathrm{R}$ & $1-1,4,7,9,10,11,12$ \\
\hline & Kuznetsky, Kemerovo District & 1 & $\mathrm{~S}$ & $\mathrm{R}$ & $\mathrm{R}$ & $\mathrm{R}$ & $\mathrm{S}$ & $\mathrm{R}$ & $\mathrm{S}$ & $\mathrm{S}$ & $\mathrm{S}$ & $\mathrm{S}$ & $\mathrm{S}$ & $1-1,7,9,10,11,12,13,14$ \\
\hline & Andrey, Kemerovo District & 1 & $\mathrm{~S}$ & $\mathrm{R}$ & $\mathrm{R}$ & $\mathrm{R}$ & $\mathrm{S}$ & $\mathrm{R}$ & $\mathrm{S}$ & $\mathrm{S}$ & $\mathrm{S}$ & $\mathrm{S}$ & $\mathrm{R}$ & $1-1,7,9,10,11,12,13$ \\
\hline \multirow{3}{*}{ ڤે } & Odessky 100, Kemerovo District & 1 & $\mathrm{~S}$ & $\mathrm{R}$ & $\mathrm{S}$ & $\mathrm{R}$ & $\mathrm{S}$ & $\mathrm{R}$ & $\mathrm{S}$ & $\mathrm{S}$ & $\mathrm{S}$ & $\mathrm{R}$ & $\mathrm{R}$ & $1-1,4,7,9,10,11,12$ \\
\hline & Kuznetsky, Kemerovo District & 1 & $\mathrm{~S}$ & $\mathrm{R}$ & $\mathrm{S}$ & $\mathrm{R}$ & $\mathrm{S}$ & $\mathrm{R}$ & $\mathrm{S}$ & $\mathrm{S}$ & $\mathrm{S}$ & $\mathrm{S}$ & $\mathrm{S}$ & $1-1,4,7,9,10,11,12,13,14$ \\
\hline & Andrey, Kemerovo District & 10 & $\mathrm{~S}$ & $\mathrm{R}$ & $\mathrm{R}$ & $\mathrm{R}$ & $\mathrm{S}$ & $\mathrm{R}$ & $\mathrm{S}$ & $\mathrm{S}$ & $\mathrm{S}$ & $\mathrm{S}$ & $\mathrm{R}$ & $10-1,7,9,10,11,12,13$ \\
\hline
\end{tabular}


Table 3. Type of reaction of varieties-differentiators for plant damage by the Ustilago nigra Tapke population (Kemerovo, 1998-1999)

\begin{tabular}{|c|c|c|c|c|c|c|}
\hline \multicolumn{7}{|c|}{ Reaction of differentiation varieties } \\
\hline k-18541 & k-15549 & k-4104 & k-3291 & k-19326 & k-17656 & k-11835 \\
Excelsior & Himalaya & Hannchen & Lion & Nepal & Pannier & Trebi \\
\hline $0.0 \mathrm{R}$ & $0.0 \mathrm{R}$ & $20.1 \mathrm{~S}$ & $25.0 \mathrm{~S}$ & $0.0 \mathrm{R}$ & $1.9 \mathrm{~S}$ & $41.3 \mathrm{~S}$ \\
\hline
\end{tabular}

Note: The numerator gives the damage percentage, the denominator - the type of reaction.

We evaluated positively and recommended new sources of resistance to loose smut $(0.0 \%)$ : Moskovsky 3/125 (k-29977), Suzdalets (k-30314), Ramos (k-30315) from the Moscow Region; M-11759 (k-30434) from the Voronezh; Zernograd 492 (k-29903) from the Rostov Region; Kumir Odessky (to-30316) from Ukraine, line 53 from Belarus and others. Absolutely immune and practically resistant were Siberian varieties Simon and Luka and breeding lines. Their breeding backgrounds include varieties of intensive type with stable productivity: Mutant 53 (Leningrad Region), Bagan (Novosibirsk Region), Viola (Moldova), Gregor (France), Vanja (Sweden), line 25 (Omsk Region).

The groups of practically resistant (up to $5 \%$ ) and weak-reactive $(5.1-10.0 \%)$ include varieties from the European part of Russia - Chelyabinsk 70 (k-29470), G-39 (k-29656), M-11763 -11763); Ukraine - Donetsk 10 (k-29612), Nutans 752 (k-29786); Belarus - Basis (k-29338), Baken (k-29339), line 16 Roland (k-30118); Canada - Guardian (k-30160); United States Composite Hybrid XVIII (k-29823); Sweden- Ingve (k-30023), WW 7272 (k-30128) and others.

Some valuable varieties and target lines of Siberian origin (C-105-270, C-46-26-77, Krasnoyarsk Krai, KM-6, KM-7, KM-16, Kemerovo Region) and Europe (Bankuti Korai, Hungary; Steine, Canada) are classified as medium- and highly-responsive. They have high adaptability to soil and climatic conditions, large grain, high protein content and the ability to form a high grain yield. They can be crossed. To increase resistance to phytopathogens, it is necessary to use highly immune varieties as a second parental form.

The group of resistant varieties, to a black loose smut included $81 \%$ of the varieties studied. There was $10 \%$ of varieties practically resistant to damage (up to $5 \%$ ). Other samples were classified as weakly responsive. Their level of damage varies from 5.0 to $25.0 \%$. One variety - Trebi (k-11835, the USA) possesses the average responsiveness to $U$. nigra Tapke. (25.1-50.0\%). It is damaged by $41.3 \%$.

The gene pool of barley from Siberia is immune to U. nigra Tapke. It is represented by breeding lines 1 . 1899, KM-18, KM-25, 72/97, 74/97, highly adaptive to the conditions of cultivation, and promising varieties of a new generation, Simon and Luka.

Most varieties from Russia are resistant to U. nigra Tapke. Moskovsky 3/125 (k-29977), Suzdalets (k-30314); Lizin (k-29711), Pirat 1 (k-27908); Taganay (k-29001); Zernogradsky 492 (k-29903) and others. Resistance sources from Ukraine (Kumir Odessky, k-30316, Nutans 752, k-29786), Belarus (Baken, k-29338, Visit, k-29405), USA (Bridge, k-30410), Canada (Guardian, k-30160), France (Tabara, k-30565), Denmark (Ca 203801, k-30446), Sweden (Svani, k-30577, WW 7272, k-30128; WW 7024, $\mathrm{k}-30445$ ) and a number of analogue lines were identified. These analogue lines were obtained by backcrossing from varieties Zazersky 85 (Belarus), Intensivny (Belarus), HVS 19/76 (Germany), Roland (Sweden) and others.

To improve the immunity of barley plants, sources with group resistance to pathogens Ustilago nuda (Jens.) Kell. et Sw.), U. hordei (Pers.) Kell. et Sw., U. nigra Tapke are recommended. They have a high and practical resistance to the species of the smut. These varieties have a high resistance to lodging (9 points) and 1000 seed weight, (52 g), up to 27 grains per spike and agrain weight of up to $550 \mathrm{~g} / \mathrm{m}^{2}$ (Table 4).

An important stage in the study of the immunity of cultural plant species is the clarification of the mechanisms controlling this property in plants. Knowledge of the genetics of immunity allows optimal use of resistance genes for solving problems in practical breeding. We studied the donor properties of new sources of resistance to $U$. nuda (Jens.) Kell. et Sw. Evaluation of $F_{1}$ hybrids resistance to a loose smut has shown the absence of splitting in direct and in back crosses. This indicates a complete dominance of resistance $(H=1)$. Genetic control of resistance was assessed by the results of splitting of second-generation hybrids. In line 1899, resistance to damage by pathogens is controlled by two alleles. Bagan variety presumably has three dominant alleles and line 53 of HVS $91 / 76$ - two dominant alleles of resistance. They may have an epistatic interaction of genes.

The success of breeding is determined by the variability and regularity of the inheritance of quantitative traits. It is important to successfully select the parent components for hybridization and to predict the efficiency of selection of productive genotypes in splitting hybrid populations. Their phenotypic and genotypic structures are the result of the interaction of genetic factors and environmental conditions. Therefore, the greatest value is obtaining information in a specific agroclimatic zone [33, 35].

The level of variation and the degree of influence of individual quantitative traits on the grain productivity of hybrid plants in comparison with the parent varieties are revealed. Number of productive stems $((\mathrm{r}=0,72 \pm$ $0.05-0.88 \pm 0.03)$ varied from medium to strong degree $(\mathrm{CV}=17.9-30.0 \%)$, number of grains per spike $(\mathrm{r}=0.34 \pm 0.07-0.85 \pm 0.04)$ and the grain weight per main spike $(\mathrm{r}=0.20 \pm 0.07-0.86 \pm 0.04)$ varied from weak to high degree $(\mathrm{CV}=5.4-26.0 \%)$, and the 1000 seed weight $(r=0.24 \pm 0.07-0.72 \pm$ $0.05)$ slightly varied $(\mathrm{CV}=3.8-10.8 \%)$. 
Genetic information about the inheritance and inheritability of the main elements of productivity is important for choosing the selection methodology in the early generations of hybrids and predicting its effectiveness. In most hybrid combinations of the first generation from direct crosses (58.3-83.3\%), superdomination appeared. In back combinations, a decrease in the frequency of the superdominant effect (16.3-58.3\%) was observed. 58.3-83.3\% of hybrids were isolated by 1000 seed weight. They are characterized by high trait indicators: Bagan $\mathrm{x}$ Viner; Bagan x KM-16; KM-16 x Bagan; KM-7 x Bagan; 1. 53 $\operatorname{HVS}^{91} / 76$ x KM-6; KM-6 x 1. 53 HVS $91 / 76$; 1. 1899 x KM-6. 1000 seed weight for the best parent variety of Bagan from the Novosibirsk Region was $45.8 \mathrm{~g}$.

Depression was noted for all analyzed traits in $8.3-41.7 \%$ of direct and back combinations. In back combinations, $33.3-41.7 \%$ of hybrids with a weak manifestation of the trait $(\mathrm{H}<-1)$ "number of grains per main spike" were established. Inheritance of symptoms by the type of incomplete dominance of the best and worst parental form was noted in direct and back crosses in some hybrids $(8.3-41.7 \%)$. The complete dominance of a coarse-grained and highgrained parent was discovered in 1998 in single combinations. The complete dominance of a low-productivity parent variety was revealed in one hybrid in 1999.

The efficiency of selection increases with increasing heritability estimate $\left(\mathrm{h}^{2}\right)$ up to $40 \%$ and higher $[30,31]$. The combination of the nature of inheritance and the inheritability of the trait is of great importance. In five hybrid crossing combinations with manifestation of overdominance, complete and incomplete dominance of the best parent in the inheritance of the character, high and average values of heritability estimates are established: by the number of productive stems $\left(\mathrm{h}^{2}=19.0-71.0 \%\right)$, by the number of grains per spike $\left(\mathrm{h}^{2}=17.0-45.0 \%\right)$, by grain weight per main spike $\left(\mathrm{h}^{2}=14.0-52.2 \%\right)$, by 1000 seed weight $\left(h^{2}=14.0-98.0 \%\right)$, by the total grain productivity $\left(\mathrm{h}^{2}=29.3-75.2 \%\right)$. In hybrid combinations with high genetic parameters, selection yielded positive results already in the early splitting generations $\left(\mathrm{F}_{2}-\mathrm{F}_{3}\right)$. Variability of symptoms is genetically determined and less dependent on external conditions. The exception was the 1000 seed weight trait. With a low and unstable manifestation of the inheritability estimate in individual combinations over the years, the selection according to this criterion had the most positive results in $\mathrm{F}_{4}$ and $\mathrm{F}_{5}$.

The practical value in selecting according to the number of grains per spike, the productivity of the main spike and the productivity of the plant is represented by the hybrid KM-7 $\times 1.1899$; by the number of productive stems, the number of grains per spike and the grain weight from the plant $-1.1899 \times$ KM-7; by the combination of the total grain productivity of the plant with the grain weight per main spike $-1.1899 \times \mathrm{KM}-16$ and productive density -1.53 HVS $91 / 76 \times$ KM-7. Hybrid combinations Bagan $\times$ Viner; Bagan $\times$ KM-16 represented a value for all elements of productivity, except for a trait of a grain weight per main spike.

In most hybrids, the heterosis effect did not play an important role in the manifestation of the following characters: the number of productive stems, the number of grains per spike, the grain weight per main spike and the grain productivity of the plant. The value of the analyzed trait in $\mathrm{F}_{2}$ did not decrease significantly compared to $F_{1}$. In some combinations it was higher. Selection by these characters is effective in early splitting generations.

In $F_{1}$ hybrid combinations, depression of individual traits (at least in one year of study) and high indices of its heritability $(30-60 \%)$ were established. This is typical for the following combinations: Viner x Bagan; Bagan x KM-6 (by the number of productive stems); Bagan $x$ KM-6 (by the number of grains per spike); Bagan x KM-6; KM 6 x Bagan; KM 16 x Bagan (by the grain weight from the plant); 1. $1899 \times$ Wiener; Wiener x 1.1899 (by the 1000 seed weight); KM-7 x 1 . $53 \mathrm{HVS} 91 / 76$ (by grain weight per main spike). In this case, selection was more effective in later generations, when most loci passed into a homozygous state. This is due to the non-allelic interaction of genes and their inhibition of the development of quantitative traits.

The steady increase in the character in individual plants in $\mathrm{F}_{2}$ as compared to the extreme values of the parent forms indicates an increase in the efficiency of selection. The greatest appearance of transgressions was observed in hybrid populations by the grain weight per main spike and the grain weight from the plant.

A great importance for selection was also the study of the combinational ability of the selected varieties. Their values made it possible to predict the prospect of using varieties in hybridization as parental forms. The most valuable samples were those with high and stable indicators of the overall combining ability (OCA) over the years. The Bagan variety and the KM-7 breeding line were characterized by high and stable OCA effects for the majority of the traits studied. This determined the high value of hybrids with their participation: Bagan $\times$ Viner; Bagan $\times$ KM-16; $1.53 \times$ KM-7; KM-7 $\times$ 1.1899; $1.1899 \times$ KM-7.

The use of severe infectious backgrounds of infection of plants with smut fungi and long-term rejection in the field are important for identifying immunological properties for the pathogen in varieties. The use of efficient and high-performance inoculation methods for seeds and plants allows the removal of affected samples at early stages of selection and determine the reliability of identified sources of resistance. The positive effect of their introduction has been achieved in our studies and in the studies of other scientists [25, 35, 36, 37, 38].

Selected resistance donors to smut fungi (Bagan variety, line $53 \mathrm{HVS} \frac{1}{76}$, line 1899) proved themselves in breeding programs. A new hybrid fund has been created, promising breeding lines have been identified. They have been studied at all stages of the breeding process. The effectiveness of selection of immune high-productive genotypes with such research technology is high. 
Table 4. Agrobiological characteristics of sources of group resistance to smut fungi (Kemerovo, 1998-1999).

\begin{tabular}{|c|c|c|c|c|c|c|c|c|c|c|c|c|c|}
\hline \multirow{2}{*}{$\begin{array}{l}\text { All-Russia } \\
\text { Institute } \\
\text { of Plant } \\
\text { Growing } \\
\text { catalog } \\
\text { number } \\
\end{array}$} & \multirow{2}{*}{ Variety, line } & \multirow{2}{*}{ Origin } & \multirow{2}{*}{$\begin{array}{l}\text { Duration } \\
\text { of } \\
\text { vegetation } \\
\text { period, } \\
\text { days }\end{array}$} & \multicolumn{2}{|c|}{$\begin{array}{l}\text { Smut damage, } \\
\text { artificial } \\
\text { background, \% }\end{array}$} & \multirow{2}{*}{$\begin{array}{l}\text { Assessment } \\
\text { of crops } \\
\text { before } \\
\text { harvesting, } \\
\text { point }\end{array}$} & \multirow{2}{*}{$\begin{array}{c}\text { Resistance } \\
\text { to } \\
\text { lodging, } \\
\text { point }\end{array}$} & \multirow{2}{*}{$\begin{array}{c}\text { Number } \\
\text { of } \\
\text { productive } \\
\text { stems, } \\
\text { pcs } / \mathrm{m}^{2}\end{array}$} & \multirow{2}{*}{$\begin{array}{c}\text { Number } \\
\text { of grains } \\
\text { per spkie, } \\
\text { pcs. }\end{array}$} & \multirow{2}{*}{$\begin{array}{c}1000 \\
\text { seed } \\
\text { weight, g }\end{array}$} & \multicolumn{3}{|c|}{ Yield capacity, $\mathrm{g} / \mathrm{m}^{2}$} \\
\hline & & & & U. nuda & U. nigra & & & & & & 1998 & 1999 & mid \\
\hline & Andrey & Kirov Region & 72 & 61.7 & 41.1 & 4.0 & 9.0 & 413 & 18 & 45.6 & 370.0 & 363.0 & 366.5 \\
\hline & Odessky 100 & Ukraine & 75 & 73.2 & 9.4 & 3.4 & 9.0 & 394 & 20 & 47.8 & 387.8 & 383.0 & 385.0 \\
\hline & Elf & Moscow Region & 80 & 4.2 & 1.5 & 3.2 & 9.0 & 365 & 21 & 47.3 & 331.4 & 345.0 & 338.2 \\
\hline & Bagan & Novosibirsk Region & 69 & 0.0 & 0.0 & 4.5 & 9.0 & 365 & 21 & 48.4 & 350.0 & 350.0 & 350.0 \\
\hline & Line 1899 & Kemerovo Region & 75 & 0.0 & 0.0 & 5.0 & 9.0 & 370 & 22 & 46.5 & 275.0 & 400.0 & 337.5 \\
\hline 29977 & Moskovsky 3/125 & Moscow Region & 79 & 0.0 & 0.0 & 4.5 & 9.0 & 390 & 24 & 50.1 & 502.0 & 350.0 & 426.0 \\
\hline 30314 & Suzdalets & Moscow Region & 82 & 0.0 & 0.0 & 5.0 & 9.0 & 542 & 23 & 50.5 & 425.0 & 500.0 & 462.5 \\
\hline 30315 & Ramos & Moscow Region & 81 & 0.0 & 1.8 & 5.0 & 9.0 & 440 & 23 & 50.1 & 420.0 & 450.0 & 435.0 \\
\hline 29346 & Kazer & Rostov Region & 76 & 0.0 & 5.2 & 4.0 & 9.0 & 288 & 18 & 50.6 & 300.0 & 300.0 & 300.0 \\
\hline 30266 & Line $53 \mathrm{HVS}^{91} / 76$ & Belarus & 80 & 0.0 & 0.0 & 4.5 & 9.0 & 241 & 24 & 41.1 & 312.0 & 350.0 & 331.0 \\
\hline 30316 & Kumir Odessky & Ukraine & 83 & 0.0 & 0.0 & 5.0 & 9.0 & 327 & 27 & 52.2 & 200.0 & 450.0 & 325.0 \\
\hline 30160 & Guardian & Canada & 84 & 4.9 & 0.0 & 3.5 & 9.0 & 347 & 27 & 49.0 & 320.0 & 350.0 & 335.0 \\
\hline & & $\mathrm{HCP}_{05}$ & & & & & & & & & 71.5 & 59.2 & \\
\hline
\end{tabular}




\section{CONCLUSIONS}

1. In the south of Western Siberia, a technology for selecting barley for resistance to smut fungi was developed. It includes the following elements:

- study of the species and race composition of the population of smut fungi in the region;

assessment of the initial and selection material for barley for resistance to smut fungi on artificial infectious backgrounds and the search for sources of individual and group immunity from the world gene pool;

- determination of donor properties of selected genetic sources in test crosses with susceptible but highly productive varieties, adapted to local conditions;
- inclusion of immunity donors in all crossbreeding programs in different breeding areas;

- studying the variability and inheritance of quantitative traits of productivity in hybrids obtained on the basis of new immunity donors to the smut species;

selection of immune forms with high productive bushiness and the number of grains in spike in hybrid populations of barley.

2. As a result of the implementation of the elements of this technology, we have created immune highly productive varieties of a new generation of early and mid-season types: Simon and Luka (Kemerovo Region). They are included in the State register of breeding achievements since 2004 .

\section{REFERENCES}

1. Stiven E. Ul'rikh Yachmen' v proizvodstve produktov pitaniya [Barley in food production]. Zerno [Grain], 2010, no. 12. Available at: http://www.zerno-ua.com/?p=11610 (accessed 11/06/17).

2. Zelenye korma [Green fodder]. Vse o zhivotnovodstve. Teoriya i praktika [All about livestock. Theory and practice]. Available at: http://worldgonesour.ru/korma/199-zelenye-korma.html (accessed 11/06/17).

3. Evseev V.V. and Stepnovskikh A.S. Vozbuditeli golovnevykh bolezney yachmenya i ekologizatsiya mer bor'by s nimi [Patoghen agents of barley smut diseases and the ecologization of measures to combat them]. Kurgan: GIPP Zaural'e Publ., 2002.150 p.

4. Telichkina N.P. and Orlova E.A. Ustoychivost' yarovogo yachmenya k golovnevym zabolevaniyam v lesostepi Priob'ya [Stability of spring barley for smut diseases in the forest-steppe of the Ob region]. Sibirskiy vestnik sel'skokhozyaystvennoy nauki [Siberian bulletin of agricultural science], 2011, no. 9/10, pp. 33-36.

5. Orlova E.A. and Telechuina N.P. Izuchenie rasovogo sostava vozbuditeley zabolevaniy yachmenya Ustilago hordei i Ustilago nuda na territorii Zapadnoy Sibiri [Studies of race composition of causal agents of barley diseases Ustilago hordei and Ustilago nuda in the territory of Western Siberia]. Vestnik NGAU [Bulletin of NSAU], 2011, no. 2 (18), pp. 23-25

6. Bakhareva Zh.A. and Khristov Yu.A. Sozdanie sortov zernovykh kul'tur, ustoychivykh $k$ golovnevym zabolevaniyam $v$ Zapadnoy Sibiri [Creation of varieties of cereal crops resistant to smut diseases in Western Siberia]. Novosibirsk, 2003. 49 p.

7. Geshele E.E. Osnovy fitopatologicheskoy otsenki v selektsii rasteniy [Fundamentals of phytopathological evaluation in plant breeding]. Moscow, 1978. 206 p.

8. Kalashnikov K.Ya. Golovnya zernovykh kul'tur [Smut diseases of grain crops]. St. Petersburg: Kolos Publ., 1971. 85 p.

9. Krivchenko V.I. Ustoychivost' zernovykh kolosovykh $k$ vozbuditelyam golovnevykh bolezney [Resistance to pathogens of cereal smut diseases]. Moscow, 1984. 304 p.

10. Makarova M.A. Fitopatologicheskaya otsenka zernovykh kul'tur na ustoychivost' k gribnym boleznyam v usloviyakh Srednego Priamur'ya [Phytopathological assessment of cereals for resistance to fungal diseases in the Middle Amur Region]. Dal'nevostochnyy agrarnyy vestnik [Far Eastern agrarian herald], 2012, no. 3 (23), pp. 69-72.

11. Legkun I.B. Sozdanie i otsenka sortov yachmenya ozimogo na gruppovuyu ustoychivost' k golovnevym zabolevaniyam [Creation and evaluation of barley varieties of winter crops for group resistance to gland diseases]. Vavilovskiy zhurnal genetiki $i$ selektsii [Vavilov Journal of Genetics and Breeding], 2015, no. 19(2), pp. 191-196.

12. Govorova D.N., Zhivykh A.V., Ipatova N.V., and Proskuryakova M.Yu. Obzor fitosanitarnogo sostoyaniya posevov sel'skokhozyaystvennykh kul'tur v RF v 2015 godu. Prognoz razvitiya vrednykh ob"ektov v 2016 godu [Overview of the phytosanitary condition of agricultural crops in Russia in 2015. Forecast of development of harmful objects in 2016]. Moscow, 2015, pp. 466-467.

13. Krivchenko V.I. and Khokhlova A.P. Golovnevye bolezni zernovykh kul'tur [Smut diseases of grain crops]. Izuchenie geneticheskikh resursov zernovykh kul'tur po ustoychivosti $k$ vrednym organizmam [Study of genetic resources of grain crops for resistance to pests], Moscow, 2008, pp. 32-85.

14. Svirkova S.V. Geneticheskie istochniki ustoychivosti k golovnevym gribam u ovsa i yachmenya [Genetic sources of resistance to smut fungi in oats and barley]. Materialy Mezhdunarodnoy nauchnoy konferentsii [Proceedings of the International Scientific Conference]. St. Petersburg, 2009, pp. 270-274.

15. Kiray Z., Klement Z., Shoymoshi F., and Veresh I. Metody fitopatologii [Methods of phytopathology] (translated from English by S.V. Vasilyeva, Yu.G. Dyakova, S.N. Lekomtseva). Moscow: Kolos Publ., 1974. 343 p.

16. Rodina N.A. and Efremova Z.G. Metodicheskie rekomendatsii po selektsii yachmenya na ustoychivost' $k$ boleznyam i ikh primenenie $v$ NIISKh Severo-Vostoka [Methodical recommendations on the selection of barley for resistance to diseases and their application in North-East Agricultural Research Institute of the Northeast]. Moscow, 1986. 79 p.

17. Lobachev Yu.V. Statisticheskie i biometricheskie metody $v$ selektsii i semenovodstve rasteniy [Statistical and biometric methods in plant breeding and seed production]. Saratov: Saratov SAU, 2014, pp. 11, 21-27, 42-45.

18. Dospekhov B.A. Metodika polevogo opyta (s osnovami statisticheskoy obrabotki rezul'tatov issledovaniy) [Methodology of field experience (with the basics of statistical processing of research results)]. Moscow: Agropromizdat Publ., 1985. 351 p.

19. Singk R. and Chaydkhari B. Biometricheskie metody analiza kolichestvennoy izmenchivosti [Biometric methods for quantitative variability analysis]. Moscow: Deli Publ., 1979, pp. 55-57. 
20. Tsil'ke R.A and Prisyazhnaya L.T. Metodika diallel'nogo analiza iskhodnogo materiala po kolichestvennym priznakam [Method of diallelic analysis of source material by quantitative traits]. Novosibirsk, 1979. $15 \mathrm{p}$.

21. Tsil'ke R.A and Prisyazhnaya L.T. Metodika otsenki iskhodnogo materiala po kombinatsionnoy sposobnosti $v$ diallel'nykh skreshchivaniyakh [Method for assessing the source material for combinational ability in diallelic crosses]. Novosibirsk, 1979. 29 p.

22. Petr F. and Frey K. Genotypic correlation dominance and heretability of quantitative traits in oats. Crop Sci., 1966, vol. 6, no. 3, pp. 259-262.

23. Voskresenskaya G.S. and Shpot V.I. Transgressiya priznakov u gibridov Brassica L. i metodika kolichestvennogo ucheta etogo yavleniya [Transgression of traits in Brassica hybrids: amethod for quantifying this phenomenon]. Doklady VASKhNIL [Reports of the the All-Union Academy of Agricultural Sciences], 1967, no. 7, pp. 18-20.

24. Rokitskiy P.F. Vvedenie v statisticheskuyu genetiku [Introduction to statistical genetics]. Minsk, 1978, pp. 40-45.

25. Luk'yanova M.V., Bugaev V.D., and Makogonev E.I. Otsenka obshchey (OKS) i spetsificheskoy (SKS) kombinatsionnoy sposobnosti $v$ selektsii yachmenya na produktivnost' [Estimation of the overall (OCA) and specific (SCA) combination ability in barley breeding for productivity]. Trudy po prikladnoy botanike, genetike, selektsii [Proceedings of Applied Botany, Genetics, Selection], 1982, vol. 73, no. 1, pp. 70-77.

26. Metodicheskie ukazaniya po izucheniyu i sokhraneniyu mirovoy kollektsii yachmenya i ovsa [Methodical guidelines for studying and preserving the world collection of barley and oats]. St. Petersburg: State Scientific Institution "All-Russian Research Institute of Butter Industry and Cheesemaking" of the Russian Academy of Agricultural Sciences, 2012. 63 p.

27. Metodika Gosudarstvennogo ispytaniya sel'skokhozyaystvennykh kul'tur [Method of state testing of agricultural crops]. Moscow, 1985. $35 \mathrm{p}$.

28. Vavilov N.I. Selektsiya immunnykh sortov [Selection of immune varieties]. Immunitet rasteniy $k$ infektsionnym boleznyam [Immunity of plants to infectious diseases]. Moscow, 1984, pp. 355-358.

29. Zaushintsena A.V., Svirkova S.V., and Chumanova N.N. Rasovaya differentsiatsiya vidov golovni ovsa v Zapadnoy Sibiri [Race differentiation of oat smut species in Western Siberia]. Doklady i soobshcheniya na 9-y genetiko-selektsionnoy shkole-seminare [Proceedings and reports at the 9th genetic selection workshop school]. Novosibirsk, 2005, pp. 305-307.

30. Svirkova S.V., Startsev A.A., and Zaushintsena A.V. Bolezni ovsa v Zapadnoy Sibiri i geneticheskie istochniki ustoychivosti [Diseases of oats in Western Siberia and genetic sources of resistance]. Izvestiya TSHA [Proceedings of the Russian Timiryazev State Agrarian University], 2016, no. 1, pp. 108-115.

31. Shirokov A.I. and Paderina E.V. Rasprostranenie i rasovyy sostav vozbuditeley golovnevykh zabolevaniy yachmenya v Omskoy oblasti [Distribution and racecomposition of the causal agents of barley disease in the Omsk Region]. Mikologiya i fitopatologiya [Mycology and Phytopathology], 1981, vol. 15, no. 3, pp. 250-252.

32. Krivchenko V.I. Ustoychivost' zernovykh kolosovykh $k$ vozbuditelyam golovnevykh bolezney [Resistance to pathogens of cereal smut diseases]. Moscow, 1984, $304 \mathrm{p}$.

33. Surin N.A. Adaptivnyy potentsial sortov zernovykh kul'tur sibirskoy selektsii i puti ego sovershenstvovaniya (pshenitsa, yachmen', oves) [Adaptive potential of varieties of grain crops of Siberian selection and ways to improve it (wheat, barley, oats)]. Novosibirsk, 2011, pp. 384-400, 466-477.

34. Mordanov S.F. and Kamelina A.M. Rezul'taty otsenki yarovogo yachmenya na ustoychivost' $k$ pyl'noy golovne $v$ usloviyakh Khabarovskogo kraya [Results of the evaluation of spring barley for resistance to a loose smut in the conditions of the Khabarovsk Territory]. Sbornik nauchnyh trudov VASHNIL [Proceedings of the All-Union Academy of Agricultural Sciences]. Novosibirsk: Sib. Division, 1982, pp. 109-111.

35. Zaushintseva A.V. Selektsiya yarovogo yachmenya v usloviyakh Kuznetskoy kotloviny Zapadnoy Sibiri. Diss. dokt. biol. nauk [Selection of spring barley in the conditions of the Kuznetsk Basin in Western Siberia. Dr. biol. sci. diss]. St. Petersburg, 2001. 304 p.

36. Tokhetova L.A. Nasledovanie, nasleduemost' i izmenchivost' kolichestvennykh priznakov gibridov yachmenya pervogo pokoleniya v usloviyakh zasolennykh pochv risovykh sistem Kazakhstanskogo Priaral'ya [Inheritance, heritability and variability of the quantitative traits of first-generation barley hybrids in conditions of saline soils in the rice systems of the Kazakhstan Aral Sea zone]. Materialy III Mezhdunarodnoy nauchno-prakticheskoy konferentsii “Nauka i obrazovanie bez granits” [Proceedings of the III International scientific-practical conference]. Sofia, 2007, pp. 10-14.

37. Sartakova S.V. Selektsiya yachmenya na ustoychivost' k golovnevym gribam v usloviyakh Kemerovskoy oblasti. Diss. kand. s.-kh. nauk [Selection of barley for resistance to smut fungi in the Kemerovo Region. Cand. agr. sci. Diss.]. Novosibirsk, 2000. 164 p.

38. Il'in A.V. Selektsiya yarovogo yachmenya na Krasnokutskoy selektsionno-opytnoy stantsii [Selection of spring barley at the Krasnokutsk selection-experimental station]. Saratov, 2011, pp. 88-94.

\section{Aleksandra V. Zaushintsena}

Dr.Sci.(Biol.), Professor, Kemerovo State University, Kemerovo, Russian Federation

\section{Svetlana V. Svirkova}

Cand.Sci.(Agr.), Associate Professor, Kemerovo State University, Kemerovo, Russian Federation 